\title{
The Impact of Thoughts in the Creation of International Law Rules: From Former Thinkers to the Future Scholars
}

\author{
Roghieh Ebrahimi ${ }^{1} \&$ Hossein Sharifi Tarazkouhi ${ }^{2}$ \\ ${ }^{1}$ PhD Student of Public International Law, Imam Reza International University, Mashhad, Iran \\ ${ }^{2}$ Associated Professor, Department of Law, Tarbiat Modarres University, Tehran, Iran \\ Correspondence: Hossein Sharifi Tarazkouhi, Associated Professor, Department of Law, Tarbiat Modarres \\ University, Tehran, Iran, Email: hsharifit@yahoo.com
}

Received: September 2, 2016

Accepted: September 15, 2016

Online Published: October 17, 2016

doi:10.5539/mas.v11n2p33

URL: http://dx.doi.org/10.5539/mas.v11n2p33

\begin{abstract}
International law as one of the human sciences which has been formed in the light of governments' needs for regulation of relations and pertinences is a set of rules which based on the increasing complexity of international life; it has been added to its importance gradually. The international nature of rules in this science leads the main followers of international system namely government to be identified as drafters of aforementioned rules. In this research we will discussed about the status of human thoughts as the smallest subjects of international system and we try to prove this hypothesis that human thoughts had been an essential component in the formation of rules in the international legal system.
\end{abstract}

Keywords: international law, school of legal thought, legal positivism, natural law

\section{Introduction}

Intellection power is the human exclusive feature as the noblest of all creatures, the power which its emersion has been manifested in the form of words and books. The result of thinking based on rational as the noblest force in human existence is different to the number of these human beings. In other words; intellection power of the human has different result under personal features and traits and complexities and delicate thoughts of each human. When potential power of thoughts and science come together; scientific theory will be produced that regardless its validity, it will established a valuable process in the evolution of human science. This process which is the creation of intellectual and scientific frictions of pro and cons thinkers and emerge in the form of dialectical dialogue; shows hidden aspects of revealed facts and unanswered necessities of human life; the life which its persistence has a deep link with science evolution.

Law as a human science has been simulated to theories, human thoughts and beliefs and has been considered to be indebted for its rules' development (Shahbazi, 2005, 166). But the question is here that whether these theories and ideas have been influential in the development of international law or not. Certainly, the realm of international law as a scientific branch related to social life of human was not an exception and despite the youthfulness it is owed to sophisticate efforts of scholars and thinkers and all of them had small or large share to complete its rules with their ideas. In the place of explaining the scholars' opinions and thoughts of international law and their placement in the international system clause D, article 38 (1) of the Statute of the International Court of Justice is worth considering that scholars' codifications of this realm has been considered as the secondary tools of law rules discovery or in other words second source of international law.

Some authors have introduced law as a pure reflection of experts and scholars' ideology and have considered ideology as the important factor for evolution. History has been the representation of different legal thinkers' ideology but nobody can consider the placement and value of these scientific concepts equally. Each of these scientific beliefs has been tolerate ups and downs in its life. These ideas were sometimes so sublime which made the ideas convinced and forcing them to be surrendered and changed to a non-conflict rule in the international legal system; an established rule which its theorist's name has been stayed in history. Also in some cases the thought will be frustrated and forgotten in the history. In continue, we will discuss the placement of international law scholars' ideology in the history and also we will discuss about the manner of their influence on creation of international law's rules. 


\section{Direct Effect on the Establishment of the Rule}

International legal rules are necessary norms for regulation of relations of all international subjects; the relations which were one-sided in the past periods and just reflected some rules which supplied the interests of main actors in the world. From a historical prospective, the sixteenth century has been considered as the beginning period of human communities' formation with international relations. In that historical moment, the international order suffers from fragility and confusion so calling that the "international order" was a vague term and actually paradoxical phraseology will be obtained. International legal rules which is produced in this "disturbed order", will be state-oriented norms that are emerged from absolute sovereignty from expressing thoughts of prominent thinkers' ideology which protected by states.

Actually the extreme state-oriented nature of international relations in the past centuries, the absence of each past manners of governments for establishing customs and limiting agreements of multilateral and global intergovernmental have helped elevating the placement and validity of opinions and beliefs of experts in this field.

In initial formation and establishment of this rules which has been placed in a coherent template and is known as international law rules, just the name of a special state or government doesn't come to the mind; the thing that comes to the mind is the name of people such as Vitoria, Grotius and Vattle which named them with titles such as establisher of the international law, the father of international law and also it is said that most of current rules of international laws have been derived from their opinions and theories. One of the most famous rules which has been established within the international legal system is the principle of "freedom of the seas" which has been discussed for the first time in 1609 in Hugues de Groote known as Hogue Grotious and today its placement hasn't been a secret to everyone (Note 1).

Legal doctrine of "fundamental change of circumstances" which is one of the terminating conditions of international treaties and clearly it has been discussed in article 62 of Vienna convention of law treaties 1969 (Note 2); is a rule which its process of theory has been referred to one of the most important thinkers of the middle 15 century named Gentilis (Boczek Boleslaw, 2005, 9). Also his book is the first law describing about diplomatic law which was in such a way that some rules related to diplomatic securities have been referred to his theories (Zou Al-Ein, 2011, 723).

With a more accurate look, we will see that the theories or ideas of elders which have had impact on the establishment of the rules in the establishment period of international laws have been entered to international laws directly in such a way that reaching to the discussed theoretical links with established rule can be investigated easily. In other words it should be said that the absolute rulers of international relations have been seeking for establishing a discipline for their relations in the throes of need to improve communication and the emergence of new intergovernmental frictions cause by these increasing conditions. This guaranteed normative discipline of their benefits has been invoked from international legal monopoly in that time which means books of thinkers; the books which have been written for governmental demands and providing advisory recommendations to them. Without any disturbance to the validity, placement or inherent value of beliefs and opinions of past scholars it should be said that it seems that among the factors influencing on the direct entrance of past scholars' scientific theory to international legal system is that the proposed theories from them which were expressed based on legal rational but in the direction of providing national benefits; was perfect support of governments as the only effective international actors in the establishment of international standards.

Grotius as a thinker that the rule "free seas" had been referred to him, in the time of confliction of his own country Netherland with Spain and UK, he had been written a part of consultation letter which was the demand of Dutch company, established as an unknown person. In the first $16^{\text {th }}$ century the countries with powerful sea forces acclaimed for the ownership of different parts of seas and oceans. Also Grotius paid to ideology in order to support Dutch company based on the prohibition of sea possession; an ideology which established a procedure with acceptance and too much attention with supporting Dutch government that was identified as a rule in the international system.

Gentilis is another thinker in the past centuries which the rule "diplomatic immunity of ambassadors" inspired from his theories in the book of "embassy" have been entered to international legal system directly. Any of his books have been written for a particular situation. The reason of writing the book "embassy" was the lack of international standards about the diplomatic relations of states and the necessities of determining the ambassadors' legal conditions which in an incident; the responsibility of commenting on it was given to him. He was the first person who was examined this matter legally and gave it scientific aspect (Ibid, 380-381). But the question is whether the transition process of these ideas to become an international law rule is just because of 
supporting of governments who seeking for their interests? The answer is no. actually there were a lot of thinkers who made ideology in order to prove their claim and guaranteed the benefits of their government but the result in the international legal system was not durable. For example, it can be mentioned from many scholars' ideas which denied the Grotius idea of free sea and believe in ownership of seas from some of the governments but the results of their claim didn't form as a normative template (Note 3).

As it was said; advocating of states from scholar's ideas as only existence rule of international law was one of the direct entrance factors of ancients' ideas to normative templates of international law. But it seems the things that make the idea of scholar deserving for the placement such as binding legal rule are persuasive value and inferred debates of the result. in the past the absolute will of governments was the acceptance of the rules which had benefits for them; but one-sided opinion for national benefit of a particular government cannot endure ups and downs of global relations and get public acceptance and become a legal rule. Based on research, it can be inferred that steady state-oriented rules from the past scholars' ideas are covered the benefits of all governments. In other words, despite tyrannical policy of governments, the ideas are in the establishment of legal rules which have the flexibility with the international relations' condition in all the centuries and this cannot be possible without paying attention to the benefits of all international actors and guarantee their direct or indirect interests. Thus in the establishment of international normative legal system, the thinkers' ideas which were in a high placement and value, often were expressed in the direction of supply the benefits of governments and with the support of government they were gone to the international law template directly; but their entrance and continuance of these ideas which were different because of their owners just can achieve in a way that the mentioned ideas have the persuasive power and be flexible with the necessities of life.

\section{Indirect Influence on the Establishment of the Rule}

Expansion the relations between the governments have formed unwritten procedure about the common customs, beliefs and behaviors of them. Gradually and with understanding the necessities of standard's regulation governed on the relations of governments established subjugation toward formulation in the form of bilateral or multilateral conventions. This has helped to develop contractual rights and embodied a rich set of accepted standards of international law. Obtained maturity from expansion of relations and painful historical experiences such as bloody wars and understanding the necessities of governments' global coexistence were led to establish international organizations; Something that helped to promote the new international law. By strengthening the normative dimensions and the structure of international law, the reliance of governments on the beliefs of legal scientists and also their influence on the establishment of legal rules decreased gradually. The entrance of governments' agents in the assemblies of international organizations who express their ideas which were in direction with supporting their own governments resulted in the adoption and acceptance of treaties, declarations or other rules of international law that was considered as the main source of international law. In fact, in this period with the growing importance of political ideas, political thought gave its place to the legal scholars and thinkers ' ideas as government representative (Ibid., 725).

Among the influential politician thoughts in the legal rules, it can be mentioned to the prohibition idea of using force in the international relations which reflected in a message addressed to the nations of America by Aristid Briand in 1927. This idea eventually emerged in the form of Treaty of Paris 1928 or a pact known as Kellogg-Briand which prohibited and rejected using of force in the international relations. Also it can be mentioned Drago doctrine, Argentine Foreign Minister, about the prohibition of using force for contract recovery of debts and Estrada Doctrine and Tubar Doctrine, Mexico and Ecuador Foreign Ministers about identifying the governments who had influence on the establishment of international rules specially the continent of America. Another influential politician in the establishment of this rule is Friedrich Fromhold Martens who expressed his idea based on "the government of principles of humanity and the dictates of public conscience in the absence of the rule" in The Hague Peace Conference 1899 as Russia's representative. Today this idea is the fundamental principles of International humanitarian law and the most peremptory norm of it which has been included in all the international humanitarian law instruments and has been named from the name of owner of idea which is Martens clause.

Increasing diversified ideas of the scholars which have been increased over time and each of them knew themselves belonging to a particular theory with branches and sub-branches of different philosophy made the recognizing the best of them so hard. But the question is here that in this different space of the crossing result of ideas of different theory's fans, how can the legal scholars' ideas make a new rule or developing the existing rules? To answer this question, a glimpse is essential on the themes of the main school of thoughts in international law and their developments. 
Natural law school: the theory of natural law is the first though theory of international law which its primary idea has been referred to Aristotle ( Note 4) (Rezai Jo, 2010, 51). Even some knew the use of natural law word from BC centuries (Parsapour, 2002, 142). Beliefs of the followers were based on the existence of the general principle which is fixed and essential and the governments should obey them. In other words the aim of natural law is those eternal rules which are superior to governments' will and is the demanded end for human. They were requirements of nature and human intellect and anybody ruled on it without any mediator. Lawmakers should try to find them and inspire from them in the legislation and make it in a form of enforceable rules (Ibid.). The thing which makes natural law without any change was God and nature origin which the naturalists respect to these rules (Note 5). Linking the natural law with God rules in the ancient times is obvious more than before in such a way that the naturalists knew sin any of violate to the rules of natural law (Ghorbania, 2004, 42). By entering to post-Renaissance period, the naturalists tried to enter the religious and theological concepts of natural law into human jurisdiction (Ibid.). In fact, the Clergymen of middle ages and the writers of sixteenth century onwards were discussing about this theory as "nature laws" and "God rights" respectively. The non-inherent Rules of natural law was vanguard until the end of the seventeenth century in its classic meaning But after the relative maturity of international relations and producing the norms of international laws they have been embodied in another international contracts' template which its root of all rules of international law deemed as governments' will. The decline of natural law was not as the meaning of loosing of ideas. Although today there is no theory of natural law in its primary meaning (Zou Al-Ein, op.cit., 448); this school of law has been experienced a new life in the light of main core importance and the content of such ideas. In the modern natural law which some writers knew its peak in 19th century, innate intellect was alternated with God's will and introduced as the base of legal rules (Shahabi\&Nikooei, 2012, 104). Evolution of the concept of sovereign state and new developments in modern times have established a new philosophy of natural law which its fans didn't belief in unchanged principles and they knew the natural principles changeable over time and in parallel with developments in society (Zou Al-Ein, op.cit., 482). Natural law was the first school of law which tried to answer what is the law and the basis of binding rules. Actually all the primary thinkers of international law were fans of this theory and each of them tried to develop and complete it.

Legal Positivism: increasing the power of policies units enjoying absolute sovereigns which try to form a normative template based on their benefits was a factor to emergence of state-oriented legal ideas. In the other words; from the beginning of 18th century the theory of legal positivism was expanded with emergence of powerful and fanatical governments and was subsisted till the end of 19th century in the manner which one could say that some of these ideas were exaggerated. The intellectual basis of legal positivism which its theorists believed in the production of legal rules from government's will, is based on two principles. First is that the international society consists of free and independent and separate governments and these have not any superior status and legal. Second, international law is the production of governments because each government is the perfect power and its satisfaction or will whether inside or outside of the country is legal rule and law (Zou Al-Ein, op.cit., 450-451). Therefore, treaties and international contracts as representation of the explicit will of governments, was highly important.

Bynkershock as one of the founders of this school of law believes that international law is the result of intellect and customs which seems in the form of contracts and decisions of governments (Zou Al-Ein, op.cit., 453). The placement which was considered for governments based on positivism ideas was in such a way that gave international law a basis based on government's will(Ibid.). Also legal positivism as a concept which emphasized on the nature of law as a contract, lost its value with the developments of international system which most important of them was changing the concept of absolute sovereign and identifying new subjects in the international law; in such a way that excess and wasting existed in both schools notified the scholars in the next periods to think of creating new books and often syncretistic with preserving themes of mentioned legal thought. But intellectual theories which were established in the modern time of the history of international law in the form of extension were in fact the continuance ideas of positivism and natural law.

Of acceleration developments of the time from the thing which we define from the concepts of "natural low" or "legal positivism" is different with the thing which it is defined in the mind of people over the time. But the described time didn't influence on the aspects of these intellectual conflicts. In clearer words, three main aspects is the axes of conflict of these two theories. The first and the main axes of idea confliction is in the source and origin of international law. As it is said before, positivisms know each legal rule as the production of government's will enjoying the sovereignty.

In contrast, naturalists search the root of mentioned rules beyond the governments' will and in the human nature and God's nature. Second is the difference which each of the theories consider for the way of interpretation. 
In this way, positivism pay attention to the appearance of treaty's text and also the aim and will of governments; while, naturalists consider the aim of treaties and also consider the new necessaries as influential factors in the development of purpose mentioned instruments. The third ax is the conflict which they have in the defining and describing the judicial function. Positivisms provide a restricted interpretation of the role of judges as the declarer of law, while naturalists emphasize on the creative role of judge in the judicial function with broad interpretation.

However, the constant conflicts between these two theories which are evident in the expressions of their followers are still stretches. The history indicated ups and downs which the mentioned theories have gone in their lifetime. It may be said that the current period is the witness of complexity of more and more confrontation in these legal thoughts and finally positivism gradually wasted after the bloody experience of war and injustice of governance based on the national benefits and then human beings were yearning for achieving to utopia once again resorted to the idealistic doctrine of natural law. But the necessities of time developing made thinkers to consider finding a middle solution, a solution which was obtained from the context of the exchange of ideas and compromise between the fans of these two schools of legal thoughts. The obtained space from dispersed ideas belonging to different intellectual theories which was established by different legal scientists, provoked existing divisions in the legal thoughts in a way that some mentioned it as "scientific chaos" and described it impossible to select the best thinkers and relying on their ideas(Zou Al-Ein, op.cit., 725). Of course, in such circumstances it cannot be seen the expressing of any theories from the scholars which become a binding rule in international law normative system directly; any idea which is expressed regardless of its intrinsic validity will be in the dialectical process from pro and cons experts and scholars and this will limit the direct changing of thought to rule. It should be noted that the decline in adherence to the ideas of scholars will not be the meaning as decrease inherent value of scientific theories and futile of them in the international law system; But it seems that emerging friction between fans of different theories of international law has fueled the crystallization of process in the direction of indirect development of international law rules. In this process, the scientific thoughts related to a particular subject have dealt with legal debate and finally the best thought, regardless of belonging to a certain theory will create the basis for acceptance of norms and change the international costumes with obtaining global credibility. In the current time that most influential embodiment of politicians' theories is depicted in the creation of rule, the effectiveness of legal scholars' thought in creating the international law rule has been presented for making rule in the form of inspiration which has indirect influence on formation of the international law standards.

\section{Conclusion}

The absence of the superior legislative power in the international society caused that normative template of international system includes some rules which are derived from its main subjects' will that means governments. Based on this, many have known international society production of governments' will for regulating their mutual relations (Zarneshan, 2014, 21). But is it possible to ignore the placement of human in the development of international law field; a human which cannot be denied as one of the international law subjects. As it was seen, history is the evidence of human ideology; ideas and thoughts which their settlement has not conflict in the international law system as a binding rule. For this reason it must be said that in the beginning, human ideas had influence in the development of international law as the basic factor but in comparison of historical periods the form of this impact has been changed. This means that the lack of source in the establishment area of international law led elders' theories and ideas which had influence on the creation of legal rules has been entered to the international law system directly. It was in such a way that the connection of the discussed theory can be considered easily with the created rule. In simpler words, on that time their ideas were exactly the same as international law. However, today with the passage of time and the diversity of opinions and emergence of thought theories, each idea which is expressed, regardless of its inherent validity will be placed in a dialectical procedure from pro and cone experts and thinkers. This will limit direct change of thought into rule. In this process, the scientific thoughts related to particular subject have dealt with legal debate and finally the best thought, regardless of belonging to a certain theory will create the basis for acceptance of norms and change the international procedure with obtaining global credibility and actually it was the inspiration of drafters of international law rules.

\section{References}

Armstrong, D., et al. (2012). International Law and International Relations, Cambridge University Press.

Austinm, J. (1995). The Province of Jurisprudence Determined. In E. R. Wilfrid (Ed.). Cambridge University Press. 
Boczek, B. A. (2005). International Law: A Dictionary (Dictionaries of International Law), Scarecrow Press, INC.

Ghorbania, N. (2004). Different interpretations of natural law. Law and Jurisprudence, 1.

Lioyd, D. (1965). Introduction to Jurisprudence, With Selected Text, London: Stevens \& Sons.

Navkof, J. (2013). Law and political ideology, translated by Mohammad Ali Nouri in law and politics, Tehran: publication of treasure of Knowledge.

Parsapour, M. B. (2002). Natural law theory. Philosophical-theological studies, 13-14.

Rezai, J. H. (2010). Natural law theory in: A review on the philosophical theories of international law, Amir Saed lawyer and et al., Tehran: Mizan.

Shahabi, M., \& Marzieh, N. (2012). Metaphysical Law deliberation on the role of value in the process of establishing the law rule. Legal Studies, 6.

Shahbazi, A. (2005). The role of principles of in the formation and evolution of the International sources of law, Master's thesis, Faculty of Law, Mofid University of Qom.

Zarneshan, S. (2014). The formation and recognition of customary international law, Tehran: Library of Treasure of Knowledge, (2nd Eds.).

Zou, A. E. (2011). Principles of Public International Law. Tehran: Ministry of Foreign Affairs, (7th Eds.).

\section{Notes}

Note 1. Article 2 convention 1957 and articles 87,89 convention 1982, law of the seas contain provisions relating to the principle of freedom of the seas

Note 2. Article 62, convention of Vienna 1969 determines about law treaties: 1. Fundamental change in the current situation at the time of conclusion of treaties which its occurrence have not been predicted, cannot invoke as a ground for terminating or withdrawing from a treaty unless:... 2. In the following cases, fundamental change cannot invoke as a ground for terminating or withdrawing from a treaty... 3. If because of one of foregoing paragraphs, one of treaty parties have the right to invoke to the fundamental change of situation as a ground for terminating or withdrawing from a treaty; also has the right to invoke to that change as a ground for suspending the operation of the treaty.

Note 3. John Selden in 1636 wrote a book about the beliefs of Grotius and supported the claim of seas' ownership. William Welwood was an English writer who claimed in his book that coastal state adjacent to sea has the right to navigating and fishing up to one hundred nautical miles.

Note 4. Socrates, Plato, Aristotle, and followers of Stoic theory are the first thinkers of natural law. This idea have been transferred to Romian which have divided laws to 3 groups: 1. Civil laws which was allocated to Romian citizens 2. Human laws or national laws which regulate foreigners' relationship together and their relationships with Romiancitixens. 3. Natural laws which were perfect and unchanging and eternal.

Note 5. Ciceronas one of the theorists related to $\mathrm{BC}$ described natural law as below: surely the actual law is intellect which is in accordance with nature. The law which is universal immutable and eternal. Changing of this law is considered as a sin and trying to discredit it is not allowed. Will and approval of Legislative Assembly cannot abandon us from this convention. For interpreting and explaining of it, we don't need to go outside of ourselves. There are not different laws for Roma, Atenna or for present or future. There is just one unchangeable, eternal rule for all of the nations and is validated for all the times. There are not any lords except God.

\section{Copyrights}

Copyright for this article is retained by the author(s), with first publication rights granted to the journal.

This is an open-access article distributed under the terms and conditions of the Creative Commons Attribution license (http://creativecommons.org/licenses/by/4.0/). 